\title{
The Nordic Journalists of Tomorrow
}

\author{
An Exploration of First Year Journalism Students \\ in Denmark, Finland, Norway and Sweden
}

\author{
Jan Fredrik Hovden, Gunn Buørnsen, Rune Ottosen, \\ Ida Willig \& Henrika Zilliacus-Tikkanen
}

\begin{abstract}
The present article summarizes the findings of a survey among first-year journalism students in Denmark, Finland, Sweden and Norway. The survey covers a wide array of subjects including social recruitment, motivation for studying journalism, preferences regarding future journalistic working life, views on the role of journalism in society, attitudes toward the profession, journalistic ideals and ideas about what are the most important traits for journalists. The study reveals significant differences between journalism students in the Nordic countries. The analysis appears to support a 'nation type' interpretation of attitudes among journalists, linked to different national traditions, in explaining the differences found. Our results clearly indicate the importance of traditional sociological explanations of behavior for the understanding of journalistic preferences and ambitions. For example, the choice of preferred topics is strongly gendered and appears as the sexual division of labor sublimated into journalistic preferences.
\end{abstract}

Keywords: journalism education, journalism students, gender, role of journalist, Nordic journalism

\section{Introduction}

The Nordic countries are often viewed by scholars as being part of the same journalism tradition. A recent example of this is the influential Comparing Media Systems (2004) by Daniel C. Hallin and Paolo Mancini, which places the Nordic countries in the 'Democratic Corporatist' model as a type of media system characterized by high newspaper circulation, strong professionalization and state intervention (but with strong protection of press freedom). A similar history of early democratization, consensus-based governments, a history of democratic corporatism and a strong welfare state are also considered to be common Nordic traits (Hallin and Mancini 2004:67-68). Interestingly, not only do Hallin and Mancini see the Nordic countries as much closer to this ideal than the other countries they include in this type of media system (including Germany, the Netherlands, Switzerland and Austria), but they also see the Nordic countries as very similar to each other (2004:70).

Based on this, one could ask whether there also exists a common 'Nordic journalism model', with common ideas and ideals concerning what journalism - and journalists - ought to be, and to what this model should aspire? 
Given that substantial changes have taken place during the past decades in all the Nordic media systems - most prominently, the much stronger presence of large commercial actors and advertisement-based media on a national (and sometimes inter-Nordic) level - we find it particularly interesting to ask what aspirations and ideals the younger generation of prospective Nordic journalists have. Do they, for example, feel stronger animosity toward traditional state-owned journalism than toward modern advertisementdriven publications? Do they share the ideals of a 'watchdog' role for journalism, or do they see journalism as a vehicle for personal self-realization? Do they want to work in newspapers, or do they prefer television or Internet-based publications?

Until very recently, there has been little systematic data on students of journalism in the Nordic countries ${ }^{1}$. Because of this, we carried out a questionnaire study among firstyear students at 19 Nordic schools of journalism in the fall semester of 2005 . There were 474 responses. $^{2}$ In this article, we will look at some comparative differences between these first-year journalism students in Finland, Sweden, Denmark and Norway ${ }^{3}$.

We will first provide some background information on journalism education in the Nordic countries and discuss the methodology and the data, including a short discussion of the comparison between countries. Then we will present findings on the major differences between the students in the Nordic countries with regard to their backgrounds, their motivations and aspirations, the students' ideas about important traits for a journalist and their views on the role of the press and its potential in society. Finally, a summary is given ${ }^{4}$.

\section{Journalism Education in the Nordic Countries}

There are many features common to journalism education in the four Nordic countries. The schools have always developed their curricula in close cooperation, with common meetings and discussions. Nordic cooperation in the field of journalism training can be viewed in the light of broad cooperation between the Nordic countries institutionalized during the 1950s. The Nordic Council had its first session in 1953, and Finland joined three years later. The Nordic Course for Journalists started in Aarhus, Denmark, in 1958 and has since that time functioned as a meeting place and an educational site for journalists already working in the media. Even before that, in the 1920s and 1930s, short courses were arranged on a Nordic basis, and a common education was discussed occasionally, before the national programs started.

In most of the countries, the 1960s were a period of rapid development for journalism schools. A discussion about the need for research connected to professional education was initiated. Gradually, the journalism schools started to cooperate with universities, and today most schools are part of, or associated with, universities or other institutions of higher education. A common feature in the Nordic countries has been the recent growth of new, competing programs, which the existing schools have accepted only reluctantly. Even in Denmark, where the professional school DJH [Danish School of Journalism] in Aarhus was the only journalism program for a long time, there are now three different programs.

The Nordic programs also share similarities with most of the European schools. In a report on journalism training in Europe, Ami Lönnroth (1997) concludes that the member schools of the European Journalism Training Association (EJTA) generally have strong practical elements in their curricula, and favor short programs. A majority of the schools train students for all types of media, favor teachers with a background as journalists, and include internships in the media in their programs. 


\section{A Note on the Comparision of Countries}

For Emil Durkheim and Max Weber, the comparative method was seen as central to sociology because it offered a solution to the (then) emerging science's problem of reconciling competing claims and generality in social research. ${ }^{5}$ For both, the comparison of similar social phenomena across nations was seen as offering the possibility of de-contextualizing local knowledge in favor of more general, sociological knowledge. Similarly, we believe a cross-national study of Nordic journalism students has some attractive prospects. First, the differences in recruitment can tell us something about the varying status and profile of journalism in the various countries. Second, the presence of national vs. cross-national ideals and conceptions of journalism can be considered - as also suggested by Splichal and Sparks (1994:58) - as informative of the degree of professionalization of journalism. Finally, looking at how the nationally varying journalistic ideals and norms are related to different historic conditions and present journalistic markets in the national context offers both the potential for a critique of traditional national explanations and a sensitizing to the role of such particular organizational contexts in shaping the young journalistic habitus and its aspirations.

Even if it seems possible to speak of a shared Nordic model of journalism education because of the many similarities in the organization and curriculum of journalism education, a cross-national comparison encounters many difficulties and uncertainties. First, even if it is relatively easy to pick out the dominating journalism schools in each country, the principal differences between a journalism school and other forms of media studies (e.g. university courses in "media science" or TV/documentary schools) are in many cases diffuse, as many of the latter incorporate a substantial amount of journalism in their teachings and not infrequently lead to careers in journalism. Second, there are differences in the length and content of different journalism schools. Whereas most of the schools offer a two- to three-year course at the bachelor's level, Roskilde University Centre, for example, offers a degree at the master level with five years of schooling, and all three Danish journalism educations involve a minimum of one year paid internship. And whereas most traditional journalism schools are state-driven or located at a university college or a university, private schools, which often have rather different models from the traditional schools for their study program and curriculum, are increasingly common. Even more important, even if most journalism schools aim for an all-purpose journalistic education, there is usually a form of division of educational labor by tradition (and state politics) where, for example, one school will specialize in print journalism and another in broadcast journalism, or one will give extensive courses in cultural journalism but little on local news journalism. A general difference also exists between the university colleges and the universities, where the latter are usually less 'practical', in the sense that less time is allocated to journalism in realistic newsroom situations and mastery of technical equipment, and the former usually have stronger bonds with the profession. In addition, we should also bear in mind the differences in admissions criteria between the schools ${ }^{6}$.

For the reasons listed above, we have thus found it imperative to increase the comparability by reducing the original sample of institutions from 19 to 12 , and focus on the most similar institutions in each country, those being the largest, oldest and most general study programs - all between two and three years at the bachelor's level - leading toward a professional journalism career.

This, however, leads to a more general question: what are we really looking for when we ask about differences between the journalism students in the different Nordic 
countries? On the one hand, we are interested in the general differences, in what kinds of attitudes and ambitions are dominant in the students, as this tells us something about the different compositions of future journalists in each country. In which country, for example, is the students' willingness to work in a newspaper strongest? On the other hand, we are interested in suggesting an explanation for the perceived differences on a national level. We want to know -following the previous example -whether there are any differences between the willingness to work in a newspaper that are not merely the result of the varied social composition of the students (age, gender, previous journalistic experience, etc.), but need to be explained with reference to differences between the nations and their different media systems on a more general level.

\section{Data and Method}

The data used in this paper are based on a web-based questionnaire administered to every first-year student at 19 Nordic schools of journalism within three weeks after they started their education in the fall semester of 2005. ${ }^{7}$ Fifty-one percent (474) responded. Three of these schools were located in Finland (Jyväskylä, Tampere, Helsinki), three in Sweden (JMG Göteborg, MKV Mitthögskolan, Södertörn) ${ }^{8}$, three in Denmark (DJH Århus, Roskilde, Odense*) and ten in Norway (the university colleges of Oslo, Volda, Bodø and Kautokeino*, the universities of Stavanger and Bergen*, Gimlekollen School of Journalism and Communication (GSJC)*, Norwegian School of Management BI*, Bjørknes International College* and Norwegian School of Business Studies MI*).

For this paper, we have focused on the differences between the largest and most traditional vocational journalism schools in each country, resulting in a selection of twelve schools (excluding all schools marked with an asterisk above), ${ }^{9}$ totaling 391 students (63 from Finland, 74 from Sweden, 90 from Denmark and 164 from Norway). We believe that this sample of institutions allows us to make some generalizations about differences between Nordic journalism students.

It should be noted that the response rate varies considerably between the various institutions. Two institutions recorded a response rate below 30\% (Södertörn and Odense), seven between 40 and 50\% (BI, GSJC, MI, Århus, Jyväskäla, Göteborg, Mitthögskolan), and the remainder between $50 \%$ and $76 \%$. The national response rates were as follows: Finland 53\%, Sweden 41\%, Denmark 47\% and Norway 56\%. Even if we are dealing here with populations and not samples, the response rates must be considered somewhat low overall, if adequate on a national level. Based on this, we clearly have to take strong precautions in analyzing the results.

The questionnaire - which was offered in Norwegian, Swedish, Danish and Finnish translations - consisted of 74 questions covering a wide array of subjects including social recruitment, motivation for studying journalism, preferences regarding future journalistic working life, views on the role of journalism in society, attitudes toward the profession, journalistic ideals, media use and ideas about what traits are most important for journalists. ${ }^{10}$

\section{Who are the Nordic Journalism Students?}

We should first note that journalism school comes at different points in the educational careers in the Nordic countries, and because of this a career in journalism features differently in students' plans and ambitions. For the Finnish and Norwegian students, 
journalism education often appears to be only the start of a longer educational career, where half of the students are quite sure that they will undertake further education afterwards, and many are uncertain about wanting to work as a journalist. Danish students, by contrast, are older (and more often male), the majority with some form of full-time work experience, and most of them fairly sure they want to work as a journalist directly after completing journalism school. The Swedish students place themselves somewhere in between the Norwegian and Finnish students as regards age and educational background, but they have more work experience and fewer plans for taking further education. The age differences are as follows: The majority of students in Sweden, Norway and Denmark are between 22 and 24 years at the start of studies. In Finland the majority of students are younger; $46 \%$ are $20-21$ years old. Denmark has the largest number of older students; $31 \%$ are over 28 years ( $46 \%$ of the males).

Table 1. Indicators of Social Background and Selected Social Characteristics for Students of Journalism (percentages)

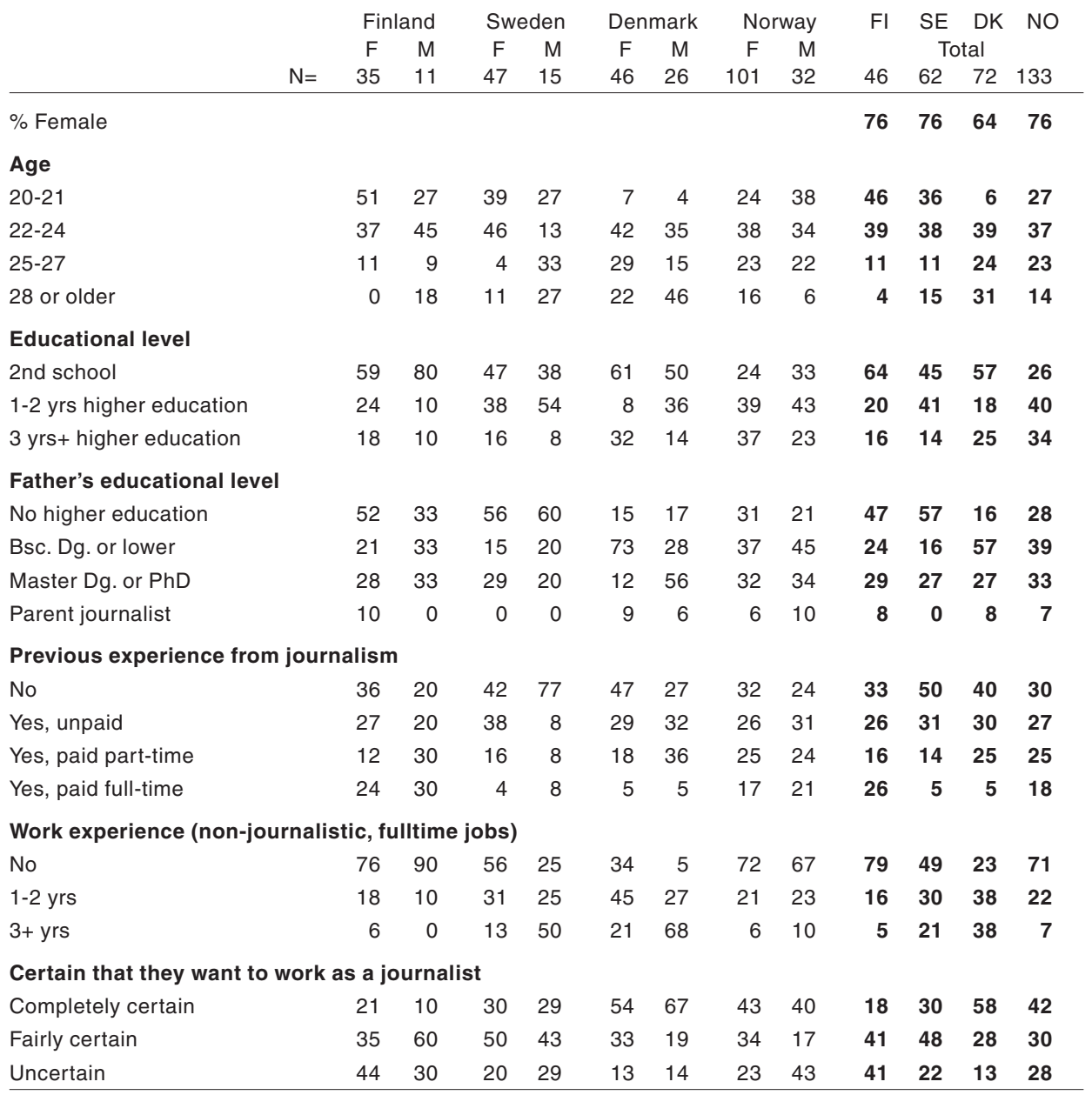

There are major differences in recruitment between the sexes in each country. In general, the Nordic female students are markedly younger than the male students, with all that 
follows, e.g. less work and educational experience on average. ${ }^{11}$ In Sweden, Norway and Finland, the proportion of women is $76 \%$, in Denmark $64 \%$.

The Nordic journalism students do not reflect society when it comes to ethnic composition: Sweden has the largest proportion of students with non-western background $(8 \%)$, while Finland has none at all. The proportion in Norway is $3 \%$ and in Denmark $1 \%$. These results are in line with an earlier survey on Nordic journalism schools' recruitment of journalists with multicultural backgrounds (Bjørnsen 2003b).

In terms of their parents' background, the differences vary. In Finland and Denmark, a lower proportion of the female students have educated parents than the male students, but the Swedish and Norwegian male and female students are more evenly matched.

\section{Motivations and Aspirations, Practical Idealist}

What are the motivations and aspirations of journalism students in the Nordic countries? The data include responses to questions from the survey regarding reasons for choosing the journalistic profession and regarding interest in specific journalistic genres and topics as well as journalistic role models. As for the motivations and aspirations of future journalists in Denmark, Finland, Norway and Sweden, they can be described in three patterns. First, that the students are practical idealists. Second, that the students aspire to the most prestigious positions and media. Third, that the students' role models are primarily TV journalists, and most often high profile correspondents. The three patterns and the differences between countries and gender will be discussed below.

An overall pattern seems to be that the Nordic journalism students are motivated by the same factors to a high degree. In the survey, the students were presented with twenty different motivations for choosing the journalistic profession and asked to grade them. The most important factor of all for students across countries and gender was "Having varied and lively work". The least important factor for all students, with only small differences from country to country and from males to females, was "Becoming a celebrity". The twenty suggested motivations can roughly be grouped into three different families of motives; practical motives, idealistic motives and personal motives. These categories will of course not be mutually exclusive. In all four countries, the overall motivation for future journalists is a mix of practical motives (for instance having varied and lively work, having a job with freedom and independence) and idealistic motives (for instance fighting injustice and working with political issues). Personal motives (such as status, wages and the possibility of becoming a celebrity) play a smaller role when the Nordic students are asked about their motivations for joining the journalistic profession. All in all, this points to a generation of journalism students who are motivated to make a difference by working in the picture of the classical fourth estate role of the press, while at the same time being motivated by the pragmatic everyday features of journalism: Practical Idealists might be the best term to describe the Nordic journalism students.

Two questions in the survey indicate great divides between the genders that, interestingly enough, do not follow the same patterns of gender in the different countries. "Helping individuals" is more important for Finnish females than for Finnish males, it is more important for Swedish males than Swedish females, more important for Danish males than females, and again more important for Norwegian females than males. Another interesting possible 'gender divider', except for Norway, is the importance of "secure employment" when choosing journalism as a profession, which is very significant to female students in Denmark, Finland and Sweden. In Finland, 44 females to 27 
males think secure employment is very important, in Sweden the corresponding figure is 54 females to 21 males, and in Denmark it is 38 females to 13 males. Norway is the only exception from this gender dividing motivation factor, as 55 females to 57 males express that secure employment is important.

Figure 1. Motivations for Becoming a Journalist. 'Very Important' or 'Somewhat Important' (percentages)

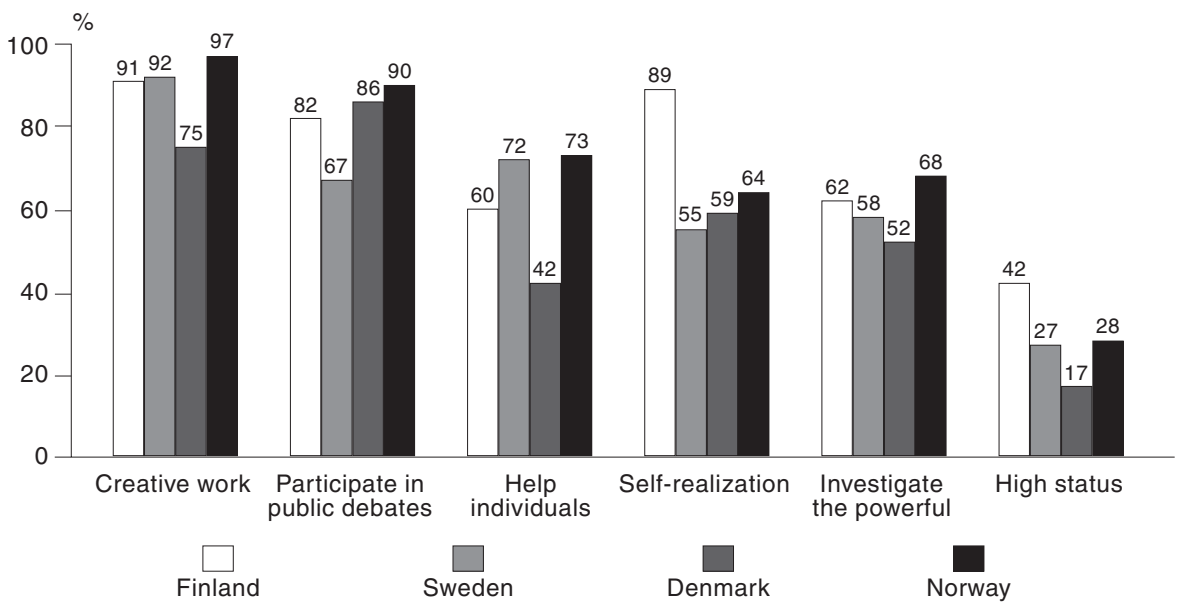

Table 2. Journalism Students' Motivations for Becoming a Journalist. 'Very Important' or 'Somewhat Important' (percentages)

\begin{tabular}{lrrrr} 
& FI & SE & DK & NO \\
\hline N= & 46 & 62 & 72 & 133 \\
Varied and lively work & 96 & 98 & 97 & 98 \\
Work with interest. subjects & 100 & 98 & 88 & 98 \\
Creative work & 91 & 92 & 75 & 97 \\
A job with freedom and independence & 82 & 88 & 77 & 92 \\
Meet interesting persons & 82 & 67 & 86 & 90 \\
The pleasure of writing & 71 & 85 & 97 & 85 \\
Participate in public debates & 89 & 92 & 83 & 87 \\
Fight injustice & 69 & 78 & 67 & 82 \\
Explaining complicated issues & 62 & 65 & 70 & 65 \\
Help individuals & 60 & 68 & 55 & 73 \\
Travel & 60 & 72 & 42 & 73 \\
Investigate the powerful & 62 & 58 & 52 & 68 \\
Secure employment & 40 & 47 & 28 & 56 \\
Good wages & 24 & 32 & 44 & 46 \\
High status & 42 & 27 & 17 & 28 \\
Becoming a celebrity & 4 & 5 & 14 & 7 \\
\hline
\end{tabular}

Gender differences regarding the question of motivation are small but interesting. 'Work with interesting subjects' is an important motivation for students in all the Nordic countries, though when it comes to Danish females, it is only slightly above average. 'The pleasure of writing' is also a general motivational factor in all the Nordic countries - only 
male students from Finland seem to put less emphasis on this question. 'Explaining/simplifying complicated issues' is moderately important as a motivation, except for male Swedish students who value this factor more than any other student group in Denmark, Finland or Norway. In analyzing these gender differences, we of course have to bear in mind the low response rate, which might produce skewed results.

\section{Prestigious Positions}

Another overall pattern is that Nordic journalism students are ambitious and well aware of the status hierarchies of the profession, in the sense that their motivations and aspirations are directed toward the most prestigious journalistic positions. In all four countries, most students are motivated by working with prestigious topics such as society/politics, culture and international conflicts. They also aspire to get jobs in the most prestigious national newspapers and on national public service television.

One of the sociological characteristics of journalistic practice is that the status hierarchies are visible in the everyday work and production of the profession: We know that political news is valued more in the internal status hierarchy, as political news is front page material. In the same way, we know that the human interest stories put in the back of the newspaper indicate a less prestigious position in the internal professional hierarchies of journalists (Schultz 2005, Schultz 2007). The data from the survey indicate that the status hierarchies of the profession are already partially internalized in the journalism students before they start working as journalists.

The survey asked the Nordic students what their interest was in working with different topics (14 classical journalistic topics). The overall picture, in all countries, points toward four topics that interest students most: Society/Politics, Culture, International conflicts and Developing countries. The runner-ups in all Nordic countries are Multicultural topics, Entertainment, Religion, Crime, Popular science and Consumer journalism. The four topics of less interest to the students as a whole (or only very interesting to a small percentage of students) are Emergencies/accidents, Health/family, Sports and Economy. These results are also in line with a longitudinal study of Norwegian journalism students. This latter study also documents that preferences for topics become more distinct during the course of studies and, especially, after entering the workforce (Bjørnsen, Hovden and Ottosen 2007a).

Looking at all of the students in all four countries, it is evident that their interest in the classical 'hard news' areas of journalism is very high. This is interesting in itself, but also interesting because of the historical change in Nordic journalism toward a more 'service oriented journalism' (Eide 1994), which has meant a move from specialist journalists to generalist journalists and a move from hard news to more consumer/soft news. The interest in journalistic topics may be one of the biggest gender dividers in the survey. For almost all topics in all countries, there are significant differences in what the female students and the male students are interested in working with. These preferences follow to a large degree the classical gender differences in society in general (Table 3).

The divide between aspirations and future job market is evident also when Nordic journalism students are asked what their first priority is with regard to workplace. Especially for Denmark and Finland, but also significant for Norway and Sweden, the national newspaper is the most sought-after, first priority for journalism students. National television is the second choice for all the countries. When it comes to working at other media, the picture is less clear. Swedish students are very interested in working 
in the magazine/popular press, which is also a wish for many Norwegian students and some Finnish students. No Danish students at all have indicated an interest in working in the magazine/popular press as a first priority. The Danish students have also indicated almost no interest in working with regional television, internet news, film, specialist magazines, trade/company magazines or in photo bureaus, which shows a very narrow area of interest for Danish journalism students compared to Finnish, Norwegian and Swedish students.

Table 3. Students' Preferred Journalistic Specializations. 'Very Interested' or 'Somewhat Interested' (percentages)

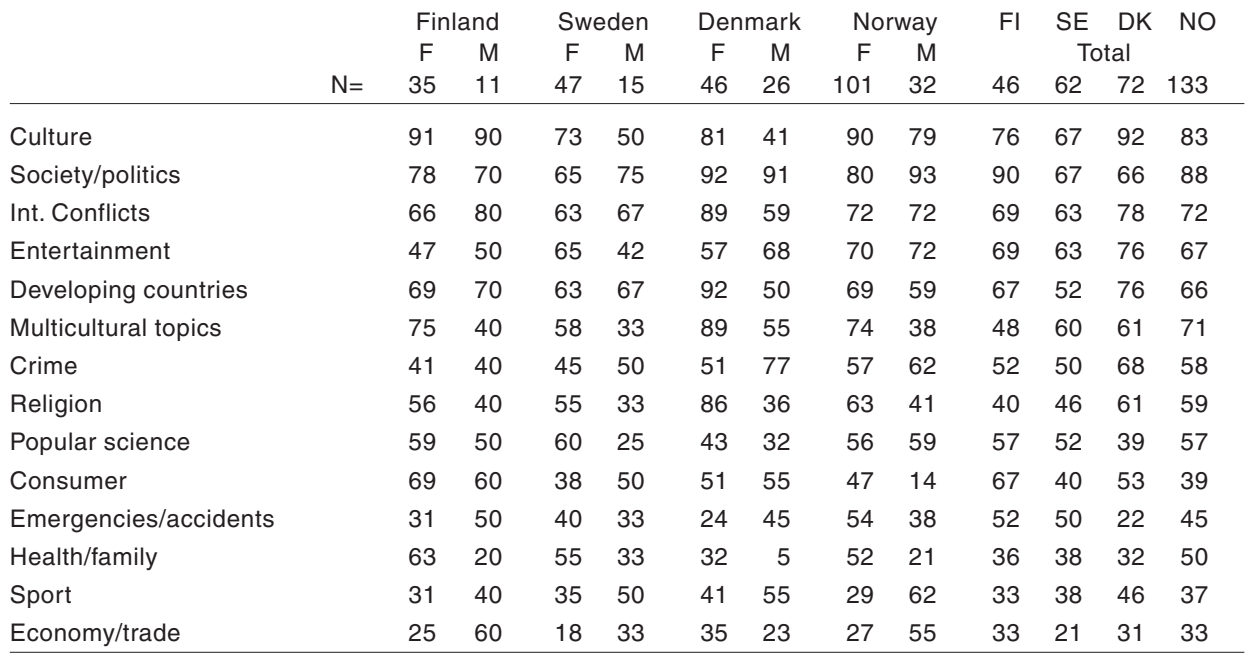

Figure 2. Students' First Choice of Future Workplace (percentages)

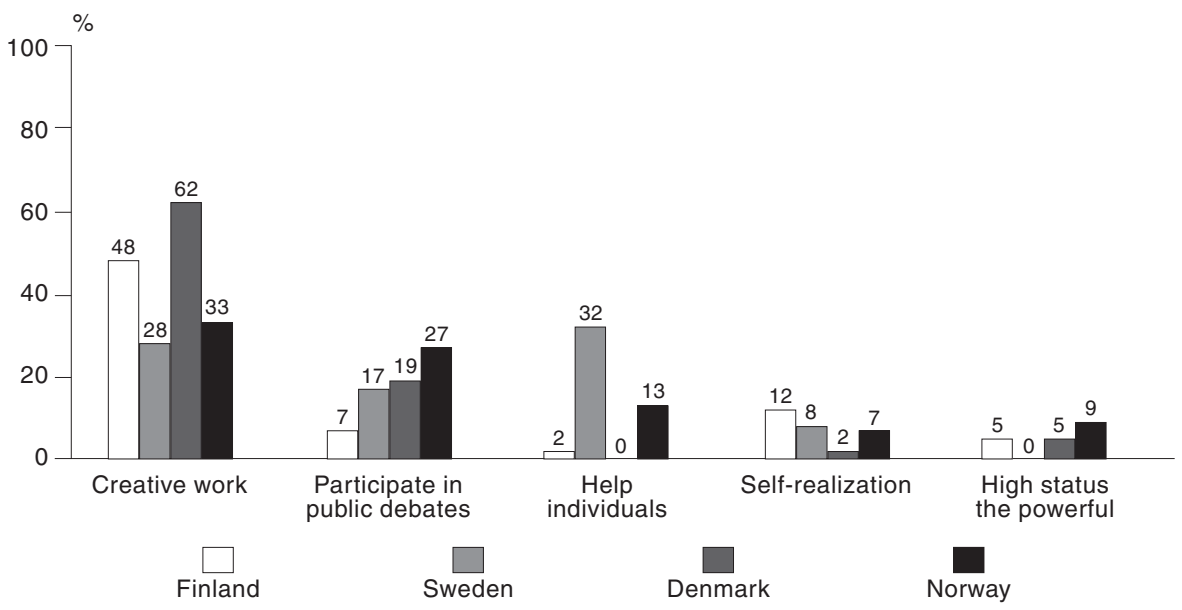

\section{The Symbolic Power Television}

An interesting finding regarding the students' motivations is that the symbolic power of television consecrates the journalistic role models in all Nordic countries. The survey asked journalism students in all four countries to name a journalistic role model. 
First, the answers to the question show that there are very many different role models from country to country and in the Nordic countries as a whole. Most of the role models are mentioned by only one student and the role models mentioned are everyone from Hunter S. Thompson to a Danish sports journalist, to a Finnish cultural journalist etc. This would seem to indicate that there are almost as many journalistic role models as there are journalism students. However, the survey shows that in each country there are a handful of journalists who are named as a role model by more than one student (Table 4).

Second, the survey shows that students in all Nordic countries place high symbolic value on a specific form of role model, the TV journalist. Looking at who these role models are, it is evident that it is almost the same type (close to stereotype) of journalist in all four Nordic countries: The middle aged, experienced, mostly male, 'serious' TV journalist (most often with a background as a correspondent or political reporter, although one of the Swedish role models is a famous interviewer/cultural journalist).

Third, the typical Nordic journalist role model is not only a middle aged, experienced TV journalist, but a special breed of TV journalist: The list of role models in Denmark, Finland, Norway and Sweden includes reporters with different beats - mainly foreign correspondents but also a few political reporters and general reporters - but what they have in common is that they all work with explaining complex issues or interpreting current situations. The finding is interesting, as one might have expected to find "the investigative reporter" or the "TV personality" or "the iconic writer at the serious newspaper" on top of the list of role models. But this is not the case. The survey clearly shows that the typical Nordic journalist role model for students is an interpretive/informing TV journalist.

The answers to this survey question can be interpreted along the lines of Pierre Bourdieu's analysis of the power of television (Bourdieu 1998 [1996]). In this perspective, journalism, in general, has a specific power to consecrate certain people, issues, etc. TV, in particular, exercises a strong symbolic power of consecration, which helps to explain why Nordic students mention interpreting/informing TV journalists as role models, even though their motivations indicate more varied interests in different roles (investigative, writing, etc.) and even though most students dream of working at a national newspaper as their first priority.

Table 4. Journalistic Role Models by Country (percentages)

Finland: Arvi Lind (13\%), Hunter S. Thompson (10\%) Others named by one student: Anna-Lena Lauren, Bosse Ahlgren, Christoffer Herberts, Hannes Heikura, Illka Malmberg, Jukka Ukkula, Kari Lumikero, Leif Salmen, Linda Skugge, Mirja Pyykkö, Pontus Dammert.

Sweden: Stina Dabrowski-Lundberg (16\%), Jan Guillou (6\%), Janne Josefsson (6\%)

Denmark: Ulla Terkelsen (14\%), Frodi Holm Knudsen (8\%), Lars Fogt (8\%), Mette Fugl (6\%), Poul E Skammelsen (6\%), Jens Olav Jersild (4\%), Niels Thorsen (4\%), Ole Sippel (4\%)

Norway: Anne Grosvold (15\%), Åsne Seierstad (8\%), Hans W Steinfeld (7\%), Marie Simonsen $(5 \%)$, John Pilger (3\%, Bjørn Hansen (2\%), Christian Borch (2\%). Frode Græsvik (2\%), Fredrik Skavlan (2\%), Knut Olsen (2\%), Per Egil Hegge (2\%)

Numbers in parenthesis = percentage of students in this country (who have named a role model) who have named this person. Only those mentioned by at least two students (three in Norway) are included, except for Finland, where role models named by one student are also included.

Open question: 'Name 1-2 persons you think are good role models for journalists'. 


\section{Journalistic Competence}

The kinds of knowledge, skills and traits that are important qualifications in journalism have rarely been researched internationally (Splichal and Sparks 1994; Deuze 2006). In the Nordic countries, the issue is also seldom discussed outside the walls of the journalism teaching institutions, whereas in countries like the US, Australia and Canada, journalism education has been a hot topic among editors and journalists during the past decade (Adam 2001; Compton et al 2001; Adams and Duffield 2005).

What constitutes journalistic competence is a vital part of the core of professional values in journalism (Bjørnsen 2003; Deuze 2006). Ideas about competence also reflect ideas about what journalism is about - and for. Competence can be divided into theoretical, practical and tacit knowledge and also includes personal values and traits (Molander 1996). Here we will take a closer look at the latter. What are considered to be important traits for a good journalist seen through the eyes of the Nordic students?

Table 5. Important Traits for Good Journalists. 'Very Important' (percentages)

\begin{tabular}{|c|c|c|c|c|}
\hline & $\begin{array}{l}\mathrm{FI} \\
46\end{array}$ & $\begin{array}{l}\text { SE } \\
62\end{array}$ & $\begin{array}{l}\text { DK } \\
72\end{array}$ & $\begin{array}{l}\mathrm{NO} \\
133\end{array}$ \\
\hline Curiosity & 71 & 76 & 82 & 93 \\
\hline A sense of language & 83 & 59 & 61 & 81 \\
\hline Thoroughness & 74 & 67 & 58 & 76 \\
\hline Knowledge of society & 76 & 51 & 51 & 82 \\
\hline A sense of justice & 64 & 53 & 33 & 58 \\
\hline A creative personality & 60 & 39 & 30 & 49 \\
\hline Understand human nature & 45 & 39 & 37 & 36 \\
\hline Efficiency and speed & 38 & 27 & 16 & 42 \\
\hline Compassion & 29 & 29 & 23 & 28 \\
\hline Political neutrality & 14 & 12 & 12 & 23 \\
\hline A certain 'cheek' & 17 & 6 & 21 & 12 \\
\hline Broad life experience & 21 & 10 & 4 & 15 \\
\hline A close relationship to sources & 5 & 10 & 4 & 13 \\
\hline Knowing 'what sells' & 2 & 2 & 19 & 10 \\
\hline A charming personality & 7 & 4 & 2 & 13 \\
\hline Respect for authorities & 5 & 2 & 0 & 2 \\
\hline
\end{tabular}

Curiosity is the trait that receives the highest score among the new students overall, particularly in Denmark and Norway. This is not surprising seen in light of the heroic model of the journalist as a particularly inquisitive individual who sniffs out the good story before anyone else does.

It may be comforting for society (and the editors, too, we assume) that thoroughness is considered to be twice as important (70\%) as efficiency (33\%) among the next generation of journalists. Seen in light of the increasingly hectic work situations in the newsrooms - with the Internet as an important factor - this result may even be regarded as surprising. ${ }^{12}$ These attitudes, however, tell us little about how decisions are actually made in the daily life of the newsrooms, when the difficult choices between thoroughness and speed arise. The Norwegian and Finnish students seem to value thoroughness most (74\%-76\%), the Danish least (58\%). 
When asked an open question about traits, the students list many not appearing in our survey, including engagement, joy of storytelling, strong will, brightness, uncompromising, the ability to listen, lack of prejudice, and humility. In these answers - even though they are often contradictory - we see elements of other traits that may be considered virtues in journalism. ${ }^{13}$

An interesting difference between newsrooms and journalism schools in this respect is that newsrooms appear to regard (often vague) personal traits, such as 'a nose for news', as very important - as seen, for example, in job advertisements, where formal qualities such as a journalism education are almost never mentioned (Høyer and Ihlen 1998). In the educational system, however, personal traits are seldom explicitly put on the agenda. Does this mean that educators believe personal traits cannot be learned? Or simply that they believe them to be of little importance?

\section{The Journalist and Society: Views on the Role of the Press}

In democratic societies, journalists and the media are expected to make an impact on the democratic and political process. But what is specifically expected from the journalist will vary from country to country (Weaver 1998). In an earlier survey of Norwegian journalism students, 'informing about political issues' was on top of the list of options describing obligations toward society. After working for three years as journalists, $90 \%$ of the respondents found this 'very important'. Also, $87 \%$ considered 'watching over the powerful and revealing abuses of power' very important. These are approximately the same percentages the respondents gave as students (Bjørnsen, Hovden and Ottosen 2007a).

The research issue at stake here is: Does the strong emphasis on the 'watchdog role' have an equally strong standing in the other Nordic countries? When it came to 'a defender of individuals affected by injustice', the Norwegian cohort had the highest score, $61 \%$, and the Danish cohort had the lowest score, 26\%. The Swedish and Finnish cohorts were closer to the Norwegian position with $55 \%$ and $38 \%$, respectively. A look at some of the other statements may strengthen the claim that the watchdog role is weaker within the Danish journalist community than in the other Nordic countries. If we turn to the statement 'a journalist should regard himself an investigator of the powerful in society', we again see that the Danish students have the lowest score - only $43 \%$ 'totally agree' with that statement. The Finnish and Swedish students have a higher score, $69 \%$ and $70 \%$, respectively. In the Norwegian cohort, $58 \%$ of the respondents 'totally agree'. Again, we must acknowledge the possible limitations of this analysis due to the low response rate.

It is difficult to explain these differences. An interesting question to explore further would be whether the Danish news industry and journalism education put less emphasis on the journalist's obligation to serve society than is the case in the other Nordic countries. In the Norwegian press system, there is a strong ethos linked to journalists' mission in society, which is stated in the ethical charter (Ver Varsom-plakaten) and in the program for the national trade union (Bjørnsen, Hovden and Ottosen 2007a). The Norwegian media researcher Odd Raaum (1999) has underlined that the journalists' obligation toward society is a strong historical tradition, and that this is very strongly emphasized in the teaching and literature of their education. 
Table 6. Important Tasks for the Press in Society (percentage 'totally agree')

\begin{tabular}{|c|c|c|c|c|}
\hline $\mathrm{N}=$ & $\begin{array}{l}\mathrm{FI} \\
46 \\
\end{array}$ & $\begin{array}{r}\text { SE } \\
62 \\
\end{array}$ & $\begin{array}{r}\text { DK } \\
72 \\
\end{array}$ & $\begin{array}{l}\text { NO } \\
133 \\
\end{array}$ \\
\hline Bring forward various opinions & 72 & 68 & 64 & 64 \\
\hline Simplify and explain complicated issues & 72 & 61 & 79 & 54 \\
\hline Facilitate public debate & 74 & 70 & 30 & 66 \\
\hline Investigate the powerful & 69 & 70 & 43 & 58 \\
\hline Give objective information & 77 & 61 & 49 & 55 \\
\hline Stimulate the public to new ideas & 82 & 57 & 49 & 53 \\
\hline A defender of individuals & 38 & 55 & 26 & 61 \\
\hline Criticize injustice & 54 & 50 & 26 & 57 \\
\hline Contribute to inter-cultural understanding & 44 & 45 & 25 & 42 \\
\hline Be a neutral reporter of events & 67 & 50 & 32 & 28 \\
\hline Be free from special interests & 46 & 27 & 28 & 14 \\
\hline Influence public opinion & 21 & 14 & 19 & 32 \\
\hline Provide recreation & 21 & 18 & 32 & 21 \\
\hline One who can educate the public as consumers & 31 & 20 & 38 & 10 \\
\hline Tell the truth regardless of consequences & 15 & 32 & 11 & 17 \\
\hline Mirror common opinions & 15 & 18 & 2 & 12 \\
\hline Ensure that media businesses do well & 0 & 2 & 15 & 4 \\
\hline
\end{tabular}

\section{Threats against Journalism}

In the above-mentioned Norwegian survey, $90 \%$ of the students claimed that 'concentration of ownership' posed a threat, to a 'great extent' or 'some extent', to a 'critical and free press' (Bjørnsen, Hovden and Ottosen 2007a). In the Nordic survey, we raised the research question of whether there is a common understanding among the Nordic students concerning what should be regarded as a threat to journalism.

One of the questions posed in the Nordic study was whether it should be regarded as a threat to freedom of the press if 'several media companies are owned by the same company'. If we combine the categories 'great danger' and 'some danger', the Swedish students are the most concerned. Ninety-three percent of the Swedish students acknowledge this as a threat, while the Norwegian and Finnish students follow closely behind with $85 \%$ and $84 \%$, respectively. The Danish students are less worried $-62 \%$ consider such concentration of ownership as a threat. Again, we see that the Danish students appear less critical of the news industry than their Nordic colleagues.

When we asked about 'media owned by political parties' as a possible threat to freedom of the press, we saw greater differences between the countries than in the answer to the question about state ownership. The historical background to this question is interesting. In Sweden and Norway, the political parties have been in control of the newspapers to a much greater extent than in Denmark and Finland (Østgaard 1978). Today, the parties have lost control over the press in all the Nordic countries. Because the journalism students have grown up long after the party press system was removed, the historical differences mentioned above seem to play little or no role. The Norwegian students seem to be the most critical toward the party press: $87 \%$ say that party press poses a 'great' or 'some' danger to freedom of the press. In Sweden - which had almost as strong a party press as Norway - the figure was lower, $75 \%$. In Denmark, which had 
a weak party press tradition, the figure was $82 \%$. In the case of Norway, this may be explained by the fact that in the public debate the transition from a party-controlled to a market-driven press is usually framed as 'liberation' from the political parties (Eide 2001).

\section{Final Remarks}

In the end, then, our comparison of the answers of the new Nordic journalism students in fall 2005 seems to support one's perspective of preference: There are marked national differences in most variables, but within a general pattern of similarity. Overall, the Norwegian and Finnish students appear to be closest in their preferences, whereas the Danish students differ most from 'the Nordic norm'.

An analytical problem with our discussion is that it has focused on the apparent differences in the attitudes of the Nordic students, but tells us less of the underlying causes for these differences. The Nordic students differ in many important ways, which we believe are important in determining their basic journalistic preferences - for example, gender, and whether or not they have previous experience of journalism. It is difficult to speculate on the degree to which a difference in, for example, the ideal of 'watch dog' is indeed related to different national and journalistic traditions internalized by the students, or whether it is more an 'effect' of internalized values from previous working experience of journalism, experience that is very differently distributed among the students from the different countries. To explore this further, a series of logistic regression analyses were done where we tried to control for some of what we believe are important factors shaping the student's preferences.

The low response rate is also a clear limitation. With this in mind, we nevertheless find that our results indicate and support some substantial findings.

We find that the differences in students' aspirations and opinions on journalism in many cases seem to be related to their particular social background and experience. Having previous work experience in journalism is related to higher interest in working for a newspaper than a magazine, and go - not unexpectedly - together with many signs of identifying with the profession and its day-to-day demands: Students with experience are more often interested in working with consumer topics, sports and entertainment, they value speed and efficiency higher as important qualities in journalists, and they identify more with the role of journalists as adversaries and critics of the powerful in society. Except for a stronger interest in sports, the age of the respondents contributed little to the students' preferences.

Having previously completed higher education is associated with an even stronger ideal of the journalist as a critic of injustice and the powerful (and low regard for the ideal of neutral reporting), and a preference for society/political news over entertainment and sports But, interestingly, the students with prior higher education have higher chances of being interested in working with consumer topics and in magazines. These students also value creative ideals more highly, and feel more commitment to participating in the public debate.

Having a father or mother with journalistic experience means that one has a much higher chance of wanting to work in a newspaper, identifies more strongly with the ideals of critical investigator, but is less skeptical toward advertisement-based publications and values efficiency and speed higher. Having a father with higher education, in contrast, is significantly associated with a stronger interest in participating in the public debate, 
the obligation to give space to diverse opinions in society and less regard for demands for efficiency and speed in journalism.

Looking at the difference between female and male students, we note a difference when it comes to both preferred topics and preferred media. Male students are less interested in working for a newspaper and female students signal stronger creative ideals and prefer to work with subjects that interest them. Female students have less taste for investigative journalism and are strongly in favor of neutrality, but also feel "a sense of justice" is important. Compared to the male students, the females are also more committed to public debate both as participants and facilitators.

Our results clearly indicate the importance of traditional sociological explanations of behavior for the understanding of journalistic preferences and ambitions. For example, the choice of preferred topics is strongly gendered and appears as the sexual division of labor (Durkheim 1997) sublimated into journalistic preferences. Similarly, the link between having an educated father - here interpreted as a very general indicator of inherited social capital in Bourdieu's sense, that is, of an elevated position in the class system, and the aspiration to participate in public debate, is not altogether surprising. ${ }^{14}$

The second conclusion, however, is that even when we control for the students' backgrounds and previous experience, the differences between the countries are still significant. Even though we must beware of confusing statistical strength with analytical importance, the analysis appears to support a 'nation type' interpretation, that is, of the importance of different national traditions in explaining the differences found.

One path for further research should be to study if and how differences of national journalistic traditions and modern media structures can explain the differences we have documented. For this purpose, comparison with other, similar, international projects would no doubt be illuminating.

\section{References}

Adam, G.S. (2001) 'The Education of Journalists', Journalism 2(3): 315-339.

Adams, D. and L. Duffield (2005) Profiles of Journalism Education: What Students Are Being Offered in Australia. Journalism Education Conference, Griffith.

Alme, B., J.P. Vestad, et al. (1997) Mot alle vindar. Mediefag $i$ Volda 1971-96. Volda: Høgskulen i Volda.

Bjørnsen, G. (2003) Journalister i støpeskjeen? Om holdninger til yrke og utdanning blant journaliststudentene i Volda og Oslo. HiO-rapport 23. Oslo: Høgskulen i Oslo.

Bjørnsen, G. (2003b) Flerkulturell bakgrunn som journalistisk kompetanse? Nordisk Journalistcenter. Århus, www.njc.dk/farver

Bjørnsen, G., J.F. Hovden and R. Ottosen. (2006) Norwegian Journalism Students: Sensation Seekers or Idealists? Dresden: ICA 2006.

Bjørnsen, G., J.F. Hovden and R. Ottosen. (2007a) 'Journalists in the Making. Findings from a Longitudinal Study of Norwegian Journalism Students’, Journalism Practice, 1(3): 383-403. Routledge.

Bjørnsen, G., J.F. Hovden and R. Ottosen. (2007b) 'Fra valp til vaktbikkje. En longitudinell studie av norske journaliststudenter', Nordicom Information 29(4): 57-70.

Bjørnsen, G., J.F. Hovden, R. Ottosen, I. Schultz and H. Zilliacus-Tikkanen (2007) The Nordic Journalism Student. A Cross-national Study. Paper presented at the IAMCR conference Media, Communication, Information: Celebrating 50 Years of Theories and Practices, Paris, July 23-25, 2007.

Bourdieu, P. (1984) Distinction: A Social Critique of the Judgement of Taste. London: Routledge \& Kegan Paul.

Bourdieu, P. (1998) On Television and Journalism. London, Pluto Press.

Bourdieu, P. (2000) Pascalian Meditations. Oxford: Polity Press.

Compton, J., Mike Gasher and David Skinner (2001) 'Putting Theory to Practice: A Critical Approach to Journalism Studies', Journalism: Theory, Practice \& Criticism 2(3): 341-360, Sage Publications.

Deuze, M. (2006) 'Global Journalism Education', Journalism Studies 7(1): 19-34.

Durkheim, É. (1997) The Division of Labor in Society. New York: Free Press. 
Eide, M. (ed.) (2001) Til dagsorden! Journalistikk, makt og demokrati. Makt- og demokratiutredningen 19982003. Oslo: Gyldendal akademisk.

Glasser, T.L. (ed.) (2007) The Idea of Public Journalism. New York: Guilford Press.

Hallin, D.C. and P. Mancini (2004) Comparing Media Systems. Three Models of Media and Politics. Cambridge: Cambridge University Press.

Hanna, M., A. Ball, et al. (2006) 'What British Journalism Students Think about Ethics and Journalism.' Journalism and Mass Communication Editor 61(1).

Holm, H.-H. (2003) Journalism Education in Denmark: The Challenges of the Market and Politics. Journalism Education in Europe and North America. New York: Hampton Press.

Huber-Humes, S. (2007) 'The Real Who, What, When, and Why of Journalism', Chronicle of Higher Education 53(20).

Høst, S. (2004) Hva er en avis? Avisbegrepet fra Hellerudkomiteen til Se og Hør. Fredrikstad, Institutt for Journalistikk.

Høyer, S. and Ø. Ihlen (1998) 'Journalisters utdanning og yrkeserfaring. Et historisk tilbakeblikk', Norsk medietidsskrift(2).

Lönnroth, A. (1997) Journalism Training in Europe. Maastricht : European Journalism Training Association / EJTA.

Molander, B. (1996) Kunskap i handling. Göteborg: Bokförlaget Daidalos AB.

Ottosen, R. (1997) 'Akademisk, kommersiell eller distriktspolitisk? Journalistutdanningens jakt på identitet', Norsk medietidskrift nr. 1, 1997.

Ottosen, R. (2004) I journalistikkens grenseland. Journalistrollen mellom marked og idealer. Kristiansand: IJ/ Høyskoleforlaget.

Ragin, C. and D. Zaret (1983) 'Theory and Method in Comparative Research: Two Strategies', Social Forces 61(3): 731-754.

Ruusunoksa, L. (2006) Public Journalism and Public Sphere(s) Citizen-oriented Public Sphere at National, Regional and Local Context. Paper presented at Public Sphere(s) and Their Boundaries, Tampere 25.-27.5 .2006 .

Raaum, O. (1999) Pressen er løs! Fronter i journalistenes faglige frigjøring. Oslo: Pax.

Salokangas, R. (2003) 'Finland: The Road to Consensus in Journalism Education', in R. Fröhlich and C. HoltzBacha: Journalism Education in Europe and North America. New York: Hampton Press.

Schultz, I. (2005) Bag om nyhetskriterierne. Roskilde: Roskilde Universitetscenter, Institut for Kommunikation, Journalistik og Datalogi.

Schultz, I. (2007) 'The Journalistic Gut Feeling', Journalism Practice 1(2): 190-207.

Skog, O-J. (2004) A forklare sosiale fenomener. En regresjonsbasert tilncerming. Oslo: Gyldendal.

Splichal, S. and C. Sparks (1994) Journalists for the 21st Century : Tendencies of Professionalization among First-year Students in 22 countries. Norwood, N.J.: Ablex Pub.

Syvertsen, T. (1997) Den store TV-krigen : norsk allmennfjernsyn 1988-96. Bergen-Sandviken, Fagbokforlaget

Weaver, D.H. (ed.) (1998) The Global Journalist. New Jersey: Hampton Press.

Østgaard, E. (1978) Pressen i Norden. En bok om pressen i de nordiske land: dens historie, dens oppgaver, dens problemer. Oslo: Gyldendal.

\section{Notes}

1. With the exception of the studies of students from two Norwegian journalism schools carried out by Ottosen, Bjørnsen and Hovden between 2000 and 2005 (Bjørnsen 2003; Bjørnsen, Hovden and Ottosen 2006 and 2007a and b) and the (now rather dated) study by Splichal and Sparks, Journalists for the 21st century (1994) - which included students from the schools of Tampere (Finland) and Oslo (Norway) - updated, relevant and comparative data for research on Nordic journalism students have been in short supply.

2. The survey was planned and carried out by Jan Dyberg (Danish School of Journalism), Marina Ghersetti (University of Gøteborg), Henrika Zilliacus-Tikkanen (University of Helsinki), Rune Ottosen (Oslo University College), Gunn Bjørnsen (then Bjørknes International College, now Volda University College) and Jan Fredrik Hovden (Volda University College).

3. The Norwegian Council for Applied Media Research [Rådet for anvendt medieforskning] has been the main funding source for the Norwegian part of this project, and also for the previous studies of Norwegian journalism students in $2000-2005$. These longitudinal Norwegian surveys are the origin of the Nordic project and were part of a national research project called StudData. StudData is a quantitative panel study of 20 study programmes carried out by the Centre for the Study of Professions (CSP) at Oslo University College (www.hio.no/studdata). 
4. This article is based on a paper presented at the IAMCR conference in Paris in July 2007. The paper version is longer and also includes more results from the survey. The paper is web-published at the IAMCR homepage: http://journalism-iamcr.org/papers.php

5. Ragin and Zaret (1983:732)

6. For instance, in Denmark admission is partly based on entrance examinations, in Sweden all new students have to pass a certain 'university certificate' ('Högskoleprovet') and in Norway a certain portion of the students are given priority based on journalistic experience (earlier 30\% of the applicants, from 2006 changed to $10 \%$ ).

7. An invitation was sent personally to all students via their e-mail address, which included a HTML link to the questionnaire, which could be filled out in their web browsers.

8. Note that the original plan was also to include Swedish journalism education at Stockholm University in the sample, but we were not able to convince the staff to participate in the project.

9. Note that Roskilde is excluded because the data received from this institution included both first- and second-year students, due to a misunderstanding with the IT Department of Roskilde. And although Södertörn and Odense both have quite low response rates individually, we consider it defensible to include them in the national total.

10. Most of these questions were adapted from the studies by Bjørnsen, Hovden and Ottosen (2006).

11. Finland offers an interesting exception here, as the females are on average almost four years younger than the male students and have less frequent previous paid experience as journalists, but they often have more educational experience and work experience.

12. Results from a longitudinal study of Norwegian journalism students are similar, and also indicate that this trend remains stable in the course of the students' careers. After three years in the newsrooms, the Norwegian journalists still believe that thoroughness is as important as they did as students (Bjørnsen, Hovden and Ottosen (2007a)).

13. We are reminded here of the concerned reflections of a journalism educator after having discussed how cynicism and arrogance are treasured in journalism: 'I would want students to be able to say out loud the words 'I don't know. 'I would want them to imagine working in a newsroom where 'I don't know' is the trigger for a story, not a sign that the reporter needs to be transferred to the home-and-garden section.' (Huber-Humes 2007)

14. Confer Bourdieu (2000:165-167).

JAN FREDRIK HOVDEN, Dr.polit., Postdoc, Faculty of Media and Journalism, Volda University College,jfh@hivolda.no

GUNN BJØRNSEN, Cand.polit, Ph.d. Student, Faculty of Media and Journalism, Volda University College, gunn.bjornsen@hivolda.no

RUNE OTTOSEN, Professor, Faculty of Journalism, Library and Information Science, Oslo University College, rune.ottosen@jbi.hio.no

IDA WILliG, Ph.d., Associate professor, Department of Communication, Business and Information Technologies, Roskilde University, idaw@ruc.dk

HENRIKA ZILLIACUS-TIKKANEN, Dr.Pol.Sc., Professor, Swedish School of Social Science, University of Helsinki, henrika.zilliacus@helsinki.fi 